\title{
Assessment of Heart Rate Variability in Fibromyalgia after Micro-physiotherapy.
}

\author{
Avaliação da Variabilidade da Frequência Cardíaca na Fibromialgia após atendimento pela Micro- \\ fisioterapia.
}

Adriano Pinto Pereira(1), Eluciene Maria dos Santos Carvalho(2), Ivo Ilvan Kerppers ${ }^{(3)}$, Meiriélly Furmann(4), Juliana Aparecida Wosch Pires(4), Larissa Gulogurski Ribeiro(4), Marcos Paulo Polowei Rolão(4), Afonso Shiguemi Inoue Salgado(5).

Universidade de Fortaleza (UNIFOR), Fortaleza (CE), Brazil.

\begin{abstract}
Introduction: Fibromyalgia syndrome is characterized by musculo-skeletal pain. Heart rate variability (HRV) is a versatile and promising non-invasive marker of the autonomous nervous system. Micro-physiotherapy involves manual physiotherapy that seeks to identify the primary cause of a disease or symptom and to stimulate self-healing, in which the body recognizes the aggressor (antigen) and begins the elimination process, through cellular and tissue reprogramming. Method: The sample was composed by 15 individuals, aged between 35 and 40 years, with fibromyalgia. The Nerve Express method was used to assess the variability of the heart rate. Two sessions of micro-physiotherapy were conducted using global methods, with an interval of 45 days between sessions. Results: Based on the HRV results, the high frequency band was confirmed at $p=0.203$, with the low frequency recording a statistically significant value of $p=0.001$, thereby demonstrating sympathetic activity. Upon comparison of the mean heartbeat before and after treatment, a value of $p=0.0006$ was obtained. A value of $p=0.049$ was recorded in the analysis of the median R-R interval values. Conclusion: The use of micro-physiotherapy as a treatment method for fibromyalgia effectively improved the lives of patients by promoting sympathicotonia.
\end{abstract}

Keywords: Fibromyalgia; micro-physiotherapy; heart rate variability

\section{Resumo}

Introdução: A Sindrome Fibromiálgica é caracterizada por manifestações algicas no sistema musculo-esquelético. A Variabilidade da Frequência Cardíaca é um marcador versátil e promissor nao-invasivo de modulação do Sistema Nervoso Autônomo. A microfisioterapia é uma técnica de fisioterapia manual que consiste em identificar a causa primária de uma doença ou sintoma e estimular a auto-cura do organismo, para que o corpo reconheça o agressor (antígeno) e inicie o processo de eliminação através da reprogramação celular e tecidual. Método: Amostra foi composta por 15 indivíduos de ambos os sexos com idade entre 35 a 40 anos com Fibromialgia; Nerve Express: É um método utilizado para a avaliação da Variabilidade de Frequência Cardíaca. Foram realizadas 2 sessões de Microfisioterapia, com intervalo de 45 dias entre as sessões com métodos globais. Resultados: Através da variabilidade da frequência cardíaca verificou-se para a banda de alta frequência $p=0.203$, e baixa freqüência com $p=0.001$ sendo estatísticamente significativa, o que demonstra uma atividade simpática. Na comparação das médias dos batimentos cardíacos antes e após o atendimento obteve-se valor de $p=0.0006$. Na análise dos valores da medianas diferenças em $50 \mathrm{~ms}$ entre RR, o valor de $p=0.049$. Conclusão: Pode-se concluir que a utilização da Microfisioterapia como método de tratamento da Fibromioalgia, é um tratamento eficaz na melhora da qualidade de vida dos pacientes, uma vez que os deixa em simpaticotonia. Palavras Chave: Fibromialgia, microfisioterapia, variabilidade da frequência cardíaca.

Palavras Chave: Fibromialgia, microfisioterapia, variabilidade da frequência cardíaca.

Received: 9 May 2014. Accepted: 13 August 2014. Published: 29 August 2014.

1. Micro-physiotherapy teacher, Brazil

2. Lecturer in the University of Fortaleza, Fortaleza (CE), Brazil.

3. Laboratory of Neuroanatomy and Neurophysiology, Universidade Estadual do Centro-Oeste (UNICENTRO), Guarapuava (PR), Brazil.

4. Students at the State University of Center-West, Guarapuava (PR), Brazil.

5. School of Manual and Postural Therapy, Londrina (PR), Brazil. 


\section{INTRODUCTION}

Fibromyalgia syndrome (FS) can be defined as a chronic, real syndrome that is caused by an abnormal pain mechanism in the central nervous system and musculo-skeletal pain. Symptoms often occur in other systems and organs. ${ }^{(1)}$

FS does not exhibit an anatomical substrate in its physiopathology and its symptoms are confused with major depression and chronic fatigue syndrome. Among the disease criteria, the most notable is the sensitivity to pain in pre-established anatomical sites, known as tender points. The number of tender points is associated with a global assessment of the severity of clinical manifestations, fatigue, sleep disorders, depression and anxiety. These carriers of FS may exhibit dysautonomia in assessments of heart rate variability (HRV). ${ }^{(2)}$

$\mathrm{HRV}$ is recognized as a versatile, promising, non-invasive marker of modulations of the autonomous nervous system (ANS) and reflects the changes in the interval between heartbeats ( $R$ wave) over time. The time between one $R$ wave and the next, in milliseconds, is known as the R-R interval or the interval between beats. This measurement is becoming more and more common in assessments of the presence of diseases, the stratification of risk, autonomic dysfunction and intervention results. ${ }^{(3,4)}$

HRV analysis provides a perspective of the function of the sympathetic and parasympathetic nervous systems ${ }^{(5)}$ as it is mainly controlled by the continuous interaction of the ANS. Two components of frequency are usually distinguishable in the short-term HRV: high frequency (HF) and low frequency (LF). In normal resting conditions and healthy individuals, the parasympathetic route is dominant, resulting in a high HRV, whereas a lower HRV and health problems have been associated with an increase in sympathetic activity while at rest. (6)

Micro-physiotherapy is a manual physiotherapy technique that seeks to identify the primary cause of a disease or symptom and to stimulate self-healing, in which the body recognizes the aggressor (antigen) and begins the elimination process through cellular and tissue reprogramming. ${ }^{(7)}$

Micropalpations mobilize and stimulate different tissues of the body with specific palpations. Two hands are used to perform movements of light approach and separation, among other positions, seeking to investigate the sensation that exists between the two hands.

Based on the theoretical foundation of embryology, the depth of the palpation and the location of the body, it is possible to perceive if the life rhythm is in good working order or if there is any perceivable absence in this rhythm. These tools enable researchers to differentiate the type of aggression (emotional, physical, toxic, chemical, environmental) that is involved in a certain symptom.

There are four basic principles involved in this method: self-healing; pathological scar; homeopathic cor- rection and micropalpation. Self-healing is the basis of all living things (homeostasis, autopoiesis) and involves the capacity to self-heal, recognize and defend oneself against physical, toxic, chemical and environmental aggressors. A pathological scar occurs when the aggression is stronger than the autopoiesis or when it comes as a surprise, leading to the memorization of the injury and a pathological scar. It causes an imbalance in cells and tissues and hinders their functions. A correction gesture is applied to the pathological scar (at the location of the aggressor's entry = etiology). Homeopathic correction is performed based on the principles of homeopathy described by Hahnemann (the founder of homeopathy). It follows the two laws of similitude (similar curing similar) and infinitesimal (more dilution, more information), as described in Energetic Medicine. ${ }^{(8)} \mathrm{Mi}-$ cropalpation involves manual gestures performed by the physiotherapist on the patient's body to diagnose the etiology, investigate symptoms and stimulate the correction of the injuries identified. The technique can be applied to patients of all ages and can be therapeutic or preventative. ${ }^{(9)}$

\section{METHOD}

\section{Sample}

The sample was composed by 15 individuals (male and female), aged between 35 and 40 years, who had been monitored for the previous two years by a multidisciplinary team containing a doctor, a physical educator, a psychologist and a physiotherapist. The group was selected after a thorough rheumatology physical examination involving specific tests and questionnaires that provide a precise diagnosis of this disease.

\section{Study Location}

The present study was conducted in the Universidade de Fortaleza (Unifor) through the Nucleo de Atenção Medica Integrada. (Nami).

\section{Nerve Express Assessment}

Nerve Express is a method used to assess heart rate variability (HRV). All of the individuals in the sample were instructed to lie on their backs (dorsal decubitus). The belt, which contains a magnetic pole to capture heartbeats, was then put in place. The participants remained in this position for 126 heart beats. They were then asked to stand until the end of the collection.

\section{Inclusion and Exclusion Criteria}

All individuals who were diagnosed with fibromyalgia and had been monitored by a multidisciplinary team and completed the thorough rheumatology assessment were included in the present study. Individuals who did not wish to participate and those who had no precise 
rheumatologic diagnosis were excluded from the present study.

\section{Application of Micro-physiotherapy}

Two sessions of micro-physiotherapy were conducted, with an interval of 45 days between each session. The patient was submitted to data collection using Nerve Express and a brief anamnesis (history of present illness, personal and family history, surgical history) prior to the session of micro-physiotherapy. The sessions lasted on average 30 to 45 minutes, during which time the patient lay on a stretcher and the therapist performed micropalpations to identify the etiology and stimulate self-healing. After the session, the patient returned for further data collection using Nerve Express.

Micro-physiotherapy was conducted in a global manner. Until now, all of the tests included the basic treatment protocol (NP3), as well as the controls and corrections of the advanced levels (P3P4, P5P6, up to P7). It is important to highlight that the symptoms of the group were similar, although each patient exhibited a specific primary etiology. This primary etiology always triggered an injury cascade involving several levels. Glandular, nervous and musculo-skeletal tissues were often associated with a single cause (etiology). After the correction of the true etiology involved, the vitality of the tissues involved was reestablished.

The parathyroid and the thymus were the most involved endothermal levels. The most commonly involved endodermal, ectodermal and mesodermal levels were, respectively: the parathyroid and thymus; the nasal arch, esophagus, stomach, bladder and external genitalia, with variations; the adrenal gland, also with a number of variations. There were many variations in the mesodermal tissue and the adrenal gland was the most affected.

The present study was conducted in five stages. Data were collected before and after the two sessions of micro-physiotherapy and 60 days after the second intervention. Data were always collected by the same physiotherapist and the micro-physiotherapy sessions were always conducted by the same physiotherapist.

All of the patients will continue to be monitored by the multidisciplinary team of the previous two years. Two months after the intervention of micro-physiotherapy, associated with other previous treatment, seven patients were discharged by their doctor and assessor for inclusion in the group.

\section{Statistical Analysis}

Origin 8.0 software was used and the data were extracted from the Nerve Express database. The data were loaded into an Excel spreadsheet using the Wavelet model. The data were then analyzed for their Gaussian distribution by means of the paired t-test, with the significance level set at $p<0.05$.

\section{RESULTS}

Prior to the statistical analysis, the raw data were submitted to Wavelet transformation to decompose the time domain to the frequency domain.

Table 1. Values in the frequency domain after Wavelet transformation.

\begin{tabular}{|c|c|c|c|c|c|c|}
\hline & $\begin{array}{c}\text { Before } \\
\text { HF }\left(\mathrm{ms}^{2}\right)\end{array}$ & $\begin{array}{c}\text { After } \\
\text { HF }\left(\mathbf{m s}^{2}\right)\end{array}$ & $\begin{array}{c}\text { Before } \\
\text { LH }\left(\mathbf{m s}^{2}\right)\end{array}$ & $\begin{array}{c}\text { After } \\
\text { LH }\left(\mathbf{m s}^{2}\right)\end{array}$ & $\begin{array}{c}\text { Before } \\
\text { LH/HF }\left(\mathrm{ms}^{2}\right)\end{array}$ & $\begin{array}{c}\text { After } \\
\text { LH/HF }\left(m s^{2}\right)\end{array}$ \\
\hline Patient 1 & 0.16 & 0.164 & 0.05 & 0.07 & 3.21 & 3.23 \\
\hline Patient 2 & 0.187 & 0.168 & 0.07 & 0.04 & 2.97 & 4.31 \\
\hline Patient 3 & 0.386 & 0.168 & 0.144 & 0.05 & 0.14 & 0.97 \\
\hline Patient 4 & 0.395 & 0.156 & 0.1 & 0.04 & 0.17 & 4.1 \\
\hline Patient 5 & 0.395 & 0.355 & 0.04 & 0.04 & 0.42 & 0.28 \\
\hline Patient 6 & 0.179 & 0.168 & 0.07 & 0.04 & 3.04 & 3.77 \\
\hline Patient 7 & 0.152 & 0.164 & 0.05 & 0.07 & 3.9 & 2.8 \\
\hline Patient 8 & 0.156 & 0.168 & 0.04 & 0.04 & 4.38 & 1.52 \\
\hline Patient 9 & 0.296 & 0.246 & 0.14 & 0.04 & 0.26 & 6.56 \\
\hline Patient 10 & 0.168 & 0.168 & 0.04 & 0.04 & 0.79 & 4.04 \\
\hline Patient 11 & 0.253 & 0.156 & 0.08 & 0.04 & 6.15 & 3.79 \\
\hline Patient 12 & 0.367 & 0.382 & 0.05 & 0.14 & 0.2 & 0.13 \\
\hline Patient 13 & 0.378 & 0.394 & 0.14 & 0.09 & 0.13 & 0.17 \\
\hline Patient 14 & 0.253 & 0.394 & 0.04 & 0.05 & 7.45 & 0.21 \\
\hline Patient 15 & 0.168 & 0.156 & 0.05 & 0.04 & 3.85 & 4.71 \\
\hline Mean & 0.259533 & 0.227133 & 0.0736 & 0.055333 & 2.470667 & 2.706 \\
\hline Standard Deviation & 0.096743 & 0.095573 & 0.037667 & 0.027047 & 2.314002 & 1.955477 \\
\hline
\end{tabular}

Subtitle: $\mathrm{HF}=$ high frequency; $\mathrm{LH}=$ low frequency. 
Table 1 displays the values after analysis of the frequency domain of the patients treated and assessed based on the HRV. The statistical analysis using the paired t-test, following a normal distribution, provided the following results: there was no significant difference in the comparison of the high frequency band $(p=0.203)$; the low frequency band was statistically significant $(p=0.001)$, demonstrating sympathetic activity. In the analysis of the relationship between the low frequency and the high frequency, no significant result was found $(p=0.387)$. Note that seven $(46.66 \%)$ individuals were found to exhibit a ratio of $\mathrm{LH} / \mathrm{HF}<1$, which means they were in a vagotonic state, four (26.4\%) remained in the stage, three $(20 \%)$ altered their ratio to $\mathrm{LH} / \mathrm{HF}>1$ in a sympathicotonic state and one individual remained in the same stage $(6.9 \%)$. The ratio $\mathrm{LH} / \mathrm{HF}>1$ contained eight (53.4\%) individuals: three $(20.0 \%)$ exhibited a decreased ratio, remaining in a sympathicotonic state; one individual (6.9\%) altered their ratio to $\mathrm{LH} / \mathrm{HF}<1$; two individuals (13.3\%) exhibited an increased ratio; and one remained in the same stage (6.9\%).

The analysis of the time domain revealed associations between the mean heartbeat values of the individuals treated (HR), the root mean square of the successive differences (RMSSD), the percentage of differences greater than $50 \mathrm{~ms}$ in the R-R intervals ( $\mathrm{PNN50)}$ ) and the standard deviation (SDNN).

Figure 1 displays the comparison of the mean heartbeat values before and after treatment. The mean and standard deviation values before and after treatment were $73.29 \pm 5.99$ and $77.37 \pm 6.97$, respectively, with a value of $\mathrm{p}=0.0006$. Of the 15 participants, $13(86.6 \%)$ exhibited an increase in the mean value of heartbeats and only two (13.4\%) exhibited a decrease in the mean value of heartbeats.

With regards to the comparative analysis of the quadratic root, Figure 2 displays the maximal values, which were $4.00 \mathrm{~ms}$ and $82.60 \mathrm{~ms}$ before and after treatment, respectively, the minimal values, which were $6.500 \mathrm{~ms}$ and $8.800 \mathrm{~ms}$ before and after treatment, respectively, and the median values, which were $4.60 \mathrm{~ms}$ and 64.100 ms before and after treatment, respectively. In the statistical analysis, the RMSSD values did not exhibit normal distribution in the Wilcoxon test $(p=0.7197)$, although this result was not statistically significant.

Figure 3 displays the mean and standard deviation values for the differences between the mean intervals of $50 \mathrm{~ms}$ among the R-R intervals, with values of 50.84 and 65.64 , before and after treatment, respectively $(p=0.049)$ in the Wilcoxon test.

\section{DISCUSSION}

In order to select the form of analysis of the HRV to be used in a certain physiological condition, it is important to consider the type of register that will be perfor- med. These range from short ( 5 to 30 minutes) to long duration ( 24 hours) and can be carried out while at rest or while stimulated by breathing maneuvers or physical exercise. In general, $256 \mathrm{R}-\mathrm{R}$ intervals are required for linear analysis, whereas a larger number (approximate-

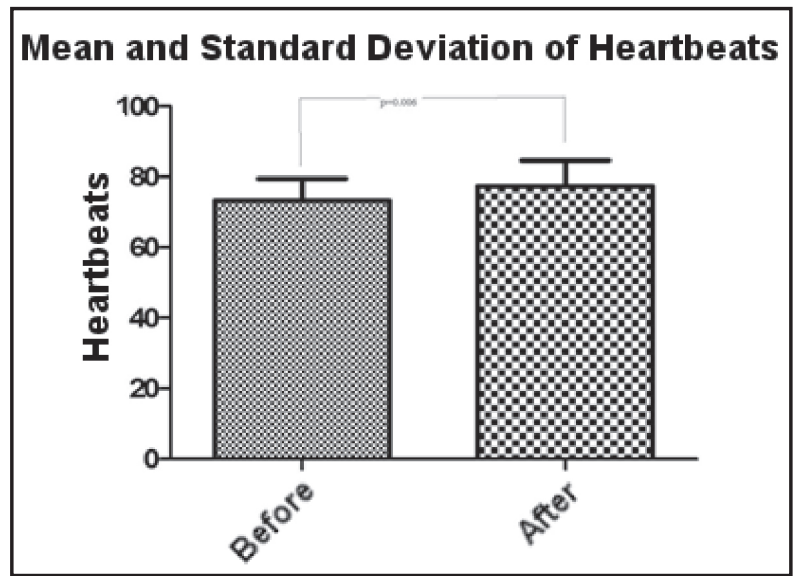

Figure 1. Mean values of heartbeat in intervals of $50 \mathrm{~ms}$, before and after the application of micro-physiotherapy, with a value of $p<0.05$.

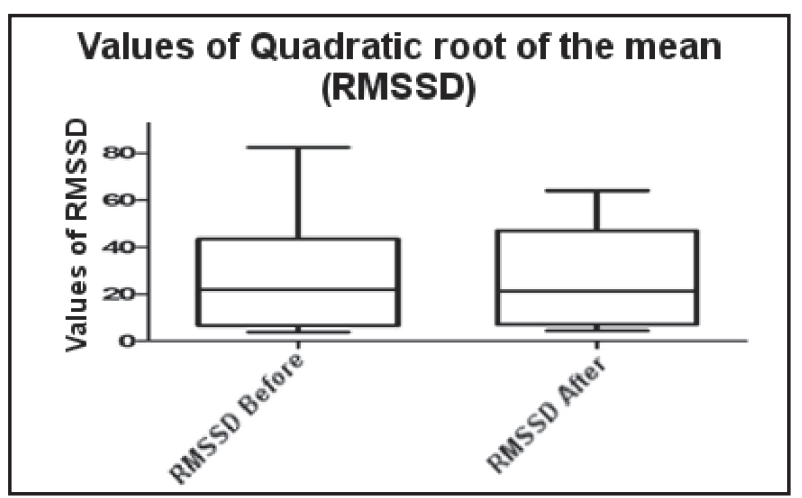

Figure 2. Maximum and minimum quadratic root values, in intervals of $50 \mathrm{~ms}$.

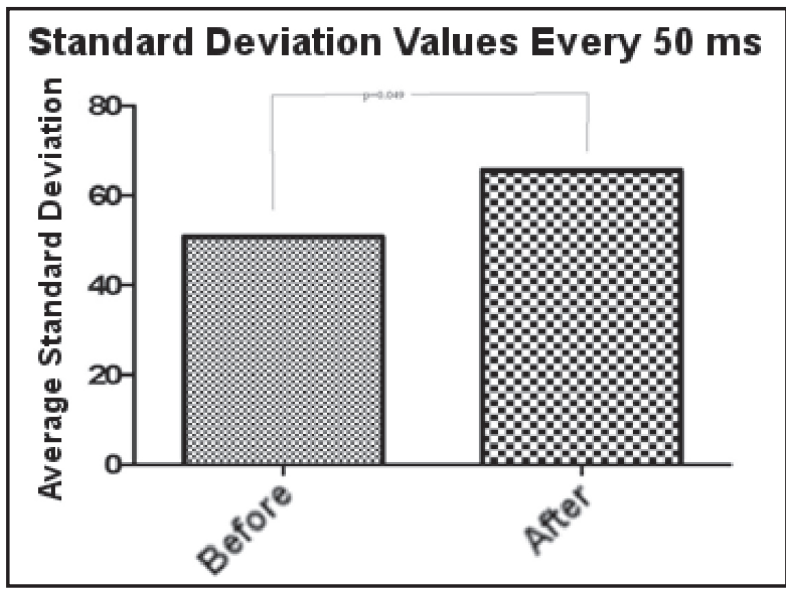

Figure 3. Mean and standard deviation values of the R-R intervals in $50 \mathrm{~ms}$, before and after the application of micro-physiotherapy, with a value of $p<0.05$ 
ly 1000 intervals) has been recommended for non-linear analysis. ${ }^{(10)}$

In the present study, the data collection conducted with Nerve Express, through the orthostatic test, considered 456 heartbeats. The most common duration was 5 minutes and 40 seconds, during which time, the linear data were treated with Wavelets for the frequency domain.

Stress provokes mental, emotional and physical reactions in humans. When stressed, the first experience of the organism is the arousal of the sympathetic nervous system, followed by the activation of the musculo-skeletal, cardiovascular and endocrine systems. The result of this process is a series of non-specific psychophysiological changes, such as an increase in certain neurotransmitters in the blood, resulting in adverse effects associated with the negative aspects of stress.

Appelhans and Luecken reported that the sympathetic system dominates the parasympathetic system during periods of stress and physiological excitement, whereas the inverse is true during periods of safety and low physiological excitement. A low HRV has been associated with a limited capacity to adapt the body to en- vironmental changes. This occurs because environmental changes are not followed by rapid adjustments of interaction between the systems of the autonomous nervous system. ${ }^{(11)}$

In the present study, the sympathetic dominance over the parasympathetic system was confirmed through the LF/HF ratio, corroborating the results of AppeIhans and Lucken (2006), who reported that the sympathetic system is predominant during stressful situations. Micro-physiotherapy acts on tissue memories and can therefore stimulate the sympathetic system. According to the abovementioned authors, a high HRV is associated with rapid adaptation to different situations, which could be correlated with the technique of micro-physiotherapy, in which a positive stimulation of memories empowers the sympathetic system, adapting it to the new situation.

\section{CONCLUSION}

The use of Micro-physiotherapy as a treatment method for fibromyalgia effectively improved the lives of patients by promoting sympathicotonia.

\section{REFERENCES}

1. Provenza JR, Pollak DF, Martinez JE, Paiva ES, Helfenstein M, Heymann R, et al. Fibromialgia(*)Rev. Bras. Reumatol. 2004; 44(6).

2. Wolfe F. The relation between tender points and fibromyalgia symptom variables: evidence that fibromyalgia is not a discrete disorder in the clinic. Ann Rheum Dis. 1997; 56:268-71.

3. Francis DP, Willson K, Georgiadou P, Wensel R, Davies LC, Coats A, et al. Physilogical basis of fractal complexity properties of heart rate variability in man. J Physiol. 2002; 542:619-29.

4. Scott AC, Francis DP, Davies LC, Ponikowski P, Coats AJS, Piepoli MF. Contribution of skeketal muscle 'ergoreceptors' in th human leg to respiratory control in chronic heart failure. J Physiol. 2000; 529:863-70.

5. Friedman BH, Thayer JF. Anxiety and autonomic flexibility: a cardiovascular approach. Biol Psychol. 1998; 49:30323.

6. Task Force of the European Society of Cardiology and the North American Society of Pacing and Electrophysiology. Heart rate variability. Standards of measurement, physiological interpretation, and clinical use. Eur Heart J. $1996 ; 17: 354-81$.

7. Menezes J. Inteligência quântica aplicções da teoria quântica na transformação humana. Besourobox, 2006.

8. Moreno JA. Medicina Energética. 4ed. Editora Hipocrática/Hahnemanniana, 2007.

9. Gorsjean D, Benini P. Lamicropalpation base de La microkinesiotherapie. France:CFM, 1990.

10. Marães VRFS. Frequencia cardíaca e sua Variabilidade: Análises e aplicações. Rev Andal Med Deporte. 2010; 3(1):33-42.

11. Appelhans BM, Luecken LJ. Heart rate variability as an index of regulated emotional responding. Rev. Gen. Psychol. 2006; 10:229-240. 